\title{
Влияние мультипотентных стромальных клеток, адсорбированных на полимере молочной кислоты, на воспалительную реакцию после его экспериментальной имплантации
}

\section{И. В. Майбородин ${ }^{1}$, Т. В. Михеева ${ }^{1}$, В. И. Майбородина ${ }^{2}$, А. И. Шевела ${ }^{1}$ \\ ${ }^{1}$ Институт химической биологии и фундаментальной медицины СО РАН, г. Новосибирск, \\ ${ }^{2}$ Институт молекулярной патологии и патоморфологии \\ ФГБНУ «Федеральный исследовательский центр фундаментальной и трансляционной медицины» МНВО РФ, г. Новосибирск \\ Impact of multipotent stromal cells, adsorped on polymer of lactic acid, on inflammatory reaction after its experimental implantation}

\section{V. Maiborodin ${ }^{1}$, T. V. Mikheyeva ${ }^{1}$, V. I. Maiborodina ${ }^{2}$, A. I. Shevela ${ }^{1}$}

${ }^{1}$ Institute of Chemical Biology and Fundamental Medicine, RAS, SB,

${ }^{2}$ Institute of Molecular Pathology and Pathomorphology,

FSBSI "Federal Research Center of Fundamental and Translational Medicine”, Novosibirsk, Russian Federation

\section{Peфepat}

Цель. Изучить влияние аутологичных мезенхимальных мультипотентных стромальных клеток (ММСК) костномозгового происхождения, адсорбированных на полимере молочной кислоты - полилактиде (ПЛ), на воспалительный процесс после экспериментальной имплантации этого полимера.

Материалы и методы. С помощью световой микроскопии с применением люминесценции изучали изменения подкожно-жировой клетчатки крыс после имплантации ПЛ с пассивно адсорбированными на поверхности ММСК с трансфицированным геном GFP и дополнительно окрашенными Vybrant $®$ CM-Dil клеточными мембранами.

Результаты. Спустя 1 нед рядом с имплантированным ПЛ с адсорбированными ММСК методами флуоресцентной микроскопии были найдены фибробластоподобные клетки с ярким и равномерным свечением цитоплазмы при использовании родаминового фильтра. На 2-й неделе возле ПЛ присутствовали макрофаги разных размеров и форм, с интенсивной флуоресценцией множества включений в условиях применения родаминового фильтра. Далее яркость люминесценции и количество светящихся объектов прогрессивно снижались вплоть до почти полного исчезновения к 4-й неделе. В результате адсорбции на Пл ММСК уменьшается объем склерозированной клетчатки с увеличением в ней числа сосудов на $1-2$-й неделях после имплантации. В этой клетчатке в течение 1 -й недели численная плотность всех лейкоцитов и лимфоцитов ниже. Типичная капсула вокруг имплантированного ПЛ у крыс формируется только к 3-й неделе. Объем капсулы, ее васкуляризация и цитограмма лейкоцитов не зависели от адсорбции ММСК.

Выводы. При имплантации ПЛ с адсорбированными ММСК уже к 2-й неделе эти клеточные элементы из тканей фагоцитируются макрофагами, ММСК и их детрит полностью элиминируются из места введения к 4-й неделе. Адсорбция ММСК на ПЛ способствует уменышению выраженности склероза и воспалительных изменений подкожно-жировой клетчатки при увеличении ее васкуляризации на 1 - 2-й неделях после имплантации. Сроки формирования капсулы вокруг ПЛ, а также ее структура не связаны с использованием клеточных технологий.

Ключевые слова: полимер молочной кислоты; инородное тело; мезенхимальные мультипотентные стромальные клетки; склероз; воспаление; имплантация.

\section{Abstract}

Objective. To study the impact of autologous mesenchymal multipotent stromal cells (AMSC) of the bone marrow origin, adsorped on polymer of lactic acid - polylactid (PL), on inflammatory process after experimental implantation of this polymer

Materials and methods. Using light microscopy with the help of luminescence the changes in subcutaneous-adipose cellular tissue in rats after implantation of PL with passively adsorped on surface of MMSC with a transfected gene GFP and additionally coloured with Vybrant ${ }^{\circledR} \mathrm{CM}-$ Dil cellular membranes were studied.

Results. In one week near the PL implanted with adsorped MMSC, using methods of the fluorescent microscopy, the fibroblast-like cells were revealed with bright and smooth glow of cytoplasm while application of a rhodamine filter. On the second week near PL the macrophages of various size and form were present, with intense fluorescence of multiple inclusions in conditions of the rhodamine filter application. So on the luminescence brightness and the glowing objects quantity becomes progressively lowered up to almost complete elimination up to the fourth week. The sclerosed cellular tissue volume is reduced with raising of its vascularity on the $1-2-\mathrm{d}$ weeks after implantation as a result of adsorption of AMSC on PL. In this cellular tissue during the first week the numerical density of all leucocytes and lymphocytes are lower. Typical capsule around implanted PL is formed in rats up to the third week only. The capsule volume, its vascularization and cytogram of leucocytes did not depend from the MMSC adsorption.

Conclusion. While implantation of PL with adsorped MMSC already up to the second week these cellular elements from the tissues are eliminated by macrophages. AMSC and their detrit are eliminated completely from the introduction site up to the fourth week. Adsorption of AMSC on PL promotes reduction of the sclerosis severity and inflammatory changes in subcutaneous-adiposal cellular tissue in enhancement of its vascularization on the first-second weeks after the implantation. The terms of the capsule formation around PL, as well as its structure, are not connected with application of cellular technologies.

Keywords: polymer of lactic acid; foreign body; mesenchymal multipotent stromal cells; sclerosis; inflammation; implantation. 
Полимеры молочной кислоты, или полилактиды (ПЛ), являются самыми старыми и до сих пор одними из самых полезных и интересных биоразрушаемых полимеров из-за их хороших механических характеристик и исходной совместимости с организмом. Имплантаты на основе ПЛ считают перспективными материалами для замещения утраченных и поврежденных тканей. Они полностью рассасываются и удаляются из места внедрения естественным путем (цикл Кребса). ПЛ имеют управляемые механические свойства, которые можно задать при синтезе, варьируя количество поперечных связей и степень полимеризации. В имплантаты на основе ПЛ можно добавлять необходимые препараты, которые, по мере разрушения полимера, будут постепенно мигрировать в окружающие ткани и, возможно, в кровь и другие жидкости организма [1].

Методами световой микроскопии в разные сроки, в течение длительного времени (1 - 12 мес) исследовали процессы биодеградации ПЛ и особенности воспалительной реакции после внедрения этого полимера в подкожножировую клетчатку крыс. Показано, что ПЛ в подкожножировой клетчатке крыс полностью не деградирует и не абсорбируется, а инкапсулируется соединительной тканью и разрушается в течение длительного времени (более 1 года), главным образом посредством макрофагального лизиса [2]. Если ПЛ имеет острые края, повреждающие ткани, формируется толстая капсула со значительной лейкоцитарной инфильтрацией и склеротической трансформацией окружающей подкожно-жировой клетчатки. Вокруг имплантированного полимера без острых краев образуется тонкая капсула с минимальной выраженностью воспаления. Во всех наблюдениях во все сроки эксперимента, при условии наличия еще нелизированного инородного тела, в капсуле и рядом с ней были обнаружены многоядерные макрофаги со слившейся цитоплазмой (гигантские клетки инородных тел).

Согласно литературным данным, использование мультипотентных стромальных клеток (МСК), а также их экзосом уменьшает выраженность острой воспалительной реакции, причем эффективность применения кондиционной среды с клеточными везикулами во многих наблюдениях намного выше, чем эффективность введения самих МСК [3]. МСК уменышают гибель животных, ускоряют избавление от микроорганизмов и снижают интенсивность воспалительного процесса в экспериментах с моделированием сепсиса и острого респираторного дистресс-синдрома [4]. Экзосомы МСК человека снижают активность пневмонии [5]. Опубликованы очень перспективные результаты применения МСК на фоне воспалительных процессов в кишечнике [6]. Снижение активности воспалительной реакции теоретически может улучшить результаты имплантации.

Цель исследования: изучить влияние аутологичных мезенхимальных МСК костномозгового происхождения (АММСККП), адсорбированных на ПЛ, на воспалительный процесс после его экспериментальной имплантации.

\section{Материалы и методы исследования}

Работа основана на результатах морфологического исследования изменений подкожно-жировой клетчатки крыс-самцов инбредной линии Wag массой тела 180 - 200 г в возрасте 6 мес в разные сроки после имплантации ПЛ с адсорбированными АММСККП в межлопаточную область. Все манипуляции с животными выполняли под общим ингаляционным эфирным наркозом в условиях чистой операционной с соблюдением Правил проведения работ с использованием экспериментальных животных (Приказ МЗ СССР №755 от 12 августа 1977 г;; Приказ Минвуза СССР №742 от 13 ноября 1984 г.).

Получение, характеристика и подготовка АММСККП для адсорбции на полимере в эксперименте. АММСККП второго пассажа, полученные от крысы указанной линии, трансфицировали ДНК плазмиды pEGFP-N1 (Clontech Laboratories Inc., США), содержащей ген зеленого флуоресцентного белка GFP (характеризуется двумя пиками поглощения: на длине волны 395 нм - основной и на длине волны 475 нм - минорный и пиком флуоресценции на длине волны 498 нм), находящийся под контролем промотора цитомегаловируса, и ген устойчивости к неомицину, находящийся под контролем промотора вируca SV40, необходимого для последующей селекции с использованием дженетицина G418 (pEGFP-N1; Clontech Laboratories Inc., США). Трансфекцию проводили в присутствии реагента для трансфекции TurboFect (Fermentas life sciences, Inc., Канада) согласно рекомендациям производителя, применяли протокол для трансфекции суспензионных клеток, используя $1 \times 10^{6}$ клеток в 1 мл суспензии, 4 мкг ДНК плазмиды и 10 мкл реагента для трансфекции TurboFect [7 - 11].

Через 2 ч после трансфекции плазмидной ДНК белка GFP к суспензии АMМСККП добавляли краситель Vybrant ${ }^{\circledR}$ CM-DiI (Thermo Fisher Scientific, США), который окрашивает мембраны живых суспензионных или прикрепившихся клеток (максимальная абсорбция - 553 нм, эмиссия - 570 нм), из расчета 5 мкл раствора на $1 \times 10^{6}$ клеток в 1 мл среды без сыворотки, мягко тщательно перемешивали пипетированием и оставляли на 20 мин в $\mathrm{CO}_{2}-$ инкубаторе при температуре $37^{\circ} \mathrm{C}$ в условиях насыщенной влажности. Затем АММСККП центрифугировали 5 мин при 1500 оборотов в 1 мин, среду с красителем удаляли, к АММСККП добавляли новую порцию теплой среды. Процедуру удаления красителя повторяли 3 раза. Затем АММСККП ресуспензировали в теплой среде в объеме из расчета $1 \times 10^{6}$ клеток в 1 мл [9, 11].

Полимер молочной кислоты, илплантированный с АММСККП в подкожно-жировую клетчатку крыс. ПЛ poly (D, L-lactide), гомополимер молочной кислоты, использованный в данном эксперименте, синтезирован и стерилизован группой клеточной биологии ИХБФМ СО РАН (г. Новосибирск). Стерильные фрагменты ПЛ необходимого размера непосредственно перед имплантацией погружали в суспензию АММСККП на 2 ч для пассивной адсорбции в связи с тем, что живые клетки, как и клетки 
перевиваемых клеточных культур, прикрепляются к любому твердому субстрату [12].

Хирургическое вмешательство для имплантачии полимера с адсорбированными АММСККП в эксперименте. Под общим ингаляционным эфирным наркозом в условиях чистой операционной при соблюдении правил асептики и антисептики после обработки кожи спиртом скальпелем с одноразовым сменным лезвием выполняли разрез кожи длиной 1,5 - 2 см на спине животного между лопатками. Область лопатки была выбрана исходя из того, что здесь достаточно выраженная подкожная клетчатка сочетается с легкостью доступа, кроме того, далее животное не сможет преждевременно избавиться от швов. Тупым способом под кожей формировали канал длиной не менее 2 см от места разреза в сторону правой лопатки, в который вводили стерильный фрагмент ПЛ, затем послойно ушивали рану непрерывными викриловыми швами и снова обрабатывали кожу спиртом. Полимер имплантировали в сформированный канал для того, чтобы избежать влияния шовного материала и поврежденной кожи на воспалительный процесс в области полимера $[2,13]$.

В качестве контроля использовали 12 животных, которым имплантировали Пл без адсорбции АММСККП, и 12 интактных крыс. После хирургического вмешательства ни одно животное не погибло. Гнойно-воспалительные осложнения в месте операции не зарегистрированы. Всего использовано 108 крыс.

Подготовка объектов для изучения морфологчческими методами. Спустя 1, 2, 3 и 4 нед после имплантации ПЛ животных выводили из эксперимента передозировкой эфирного наркоза, биоптировали полимер вместе с окружающими тканями, фиксировали в 4\% растворе параформальдегида на фосфатном буфере $(\mathrm{pH} 7,4)$ не менее 24 ч, обезвоживали в серии растворов этанола возрастающей концентрации, просветляли в ксилоле и заключали в гистопласт. Срезы толщиной 5 - 7 мкм окрашивали гематоксилином и эозином, изучали на световом микроскопе Axioimager M1 (Zeiss, Германия) при увеличении до 1200 раз.

Неокрашенные срезы исследовали в режиме люминесценции на указанном микроскопе с фильтрами Alexa Fluor 488 (диапазон возбуждения - 450 - 490 нм, диапа-

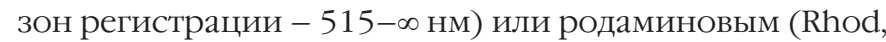
диапазон возбуждения - 540 - 552 нм, диапазон регистрации 575 - 640 нм). При получении микрофотографий использовали автоматическую экспозицию, в процессе совмещения изображений с применением фильтров Alexa Fluor 488 и родаминового можно получить зеленый и красный или оранжевый и желтый цвета в зависимости от преобладания интенсивности свечения при применении того или иного фильтра. Зеленый цвет дает более яркая флуоресценция при использовании фильтра Alexa Fluor 488, красный - на фоне применения родаминового фильтра. Желтый цвет и его оттенки получаются в результате смешения зеленого и красного цветов в той или иной пропорции.
Морфометрические методы исследования, статистическая обработка полученных данных. Для исследования структурной организации тканей вокруг ПЛ измеряли изображения, полученные при помощи цифровой видеокамеры микроскопа, на экране компьютера с использованием программного обеспечения морфологического модуля Axiovision (Zeiss, Германия). При использовании объектива с увеличением в 10 раз для определения толщины и васкуляризации тканей вокруг имплантированного полимера конечная площадь тестового прямоугольника была равна 5,6 ×10 мкм² $^{2}$ (стороны $2800 \times 2000$ мкм), при подсчете клеток (применение объектива с увеличением в 40 раз) $-8,75 \times 10^{4}$ мкм $^{2}$ (стороны $350 \times 250$ мкм). На каждом срезе проводили $3-5$ измерений с учетом рекомендаций, что для рандомизированного исследования достаточно трех срезов [14]. На случайных срезах через ПЛ с окружающими тканями определяли толщину и особенности васкуляризации капсулы с имплантированным полимером и рыхлой волокнистой соединительной ткани вокруг этой капсулы, численную плотность всех клеточных элементов на площади $10^{5}$ мкм $^{2}$ и процент лимфоцитов, нейтрофилов, эритроцитов и макрофагов от всего количества клеток. Кровеносные и лимфатические сосуды в капсуле дифференцировали от окружающих тканей в соответствии с рекомендациями J. R. Hеad и L. L. Seeling [14].

Для статистической обработки результатов использовали прикладную статистическую программу MS Excel 2010 (Microsoft Inc., США), получали среднее арифметическое и стандартное отклонение. Достоверность различий сравниваемых средних величин определяли на основании критерия Стьюдента. Достоверным считали различие между сравниваемыми рядами с уровнем доверительной вероятности 95\% и выше. При расчетах учитывали, что распределение исследуемых признаков было близким к нормальному.

\section{Результаты}

Через 1 нед после операции при изучении неокрашенных срезов тканей рядом с имплантированным Пл с адсорбированными АММСККП методами флуоресцентной микроскопии отмечали расположенные поодиночке и небольшими группами клеточные элементы, которые имели вытянутую фибробластоподобную форму. При использовании родаминового фильтра ярко и равномерно светились не четко очерченные включения, а обширные участки цитоплазмы (рuс. 1, a).

Спустя 2 нед в окружающей инородное тело соединительной ткани обнаруживали множество клеточных элементов разных размеров и формы. При использовании родаминового фильтра в них светилась не вся цитоплазма равномерно, а множество овальных включений с четкими границами (рис. 1, б).

На 3-й неделе яркую флуоресценцию в условиях применения родаминового фильтра наблюдали только в немногочисленных клеточных элементах разных форм и раз- 

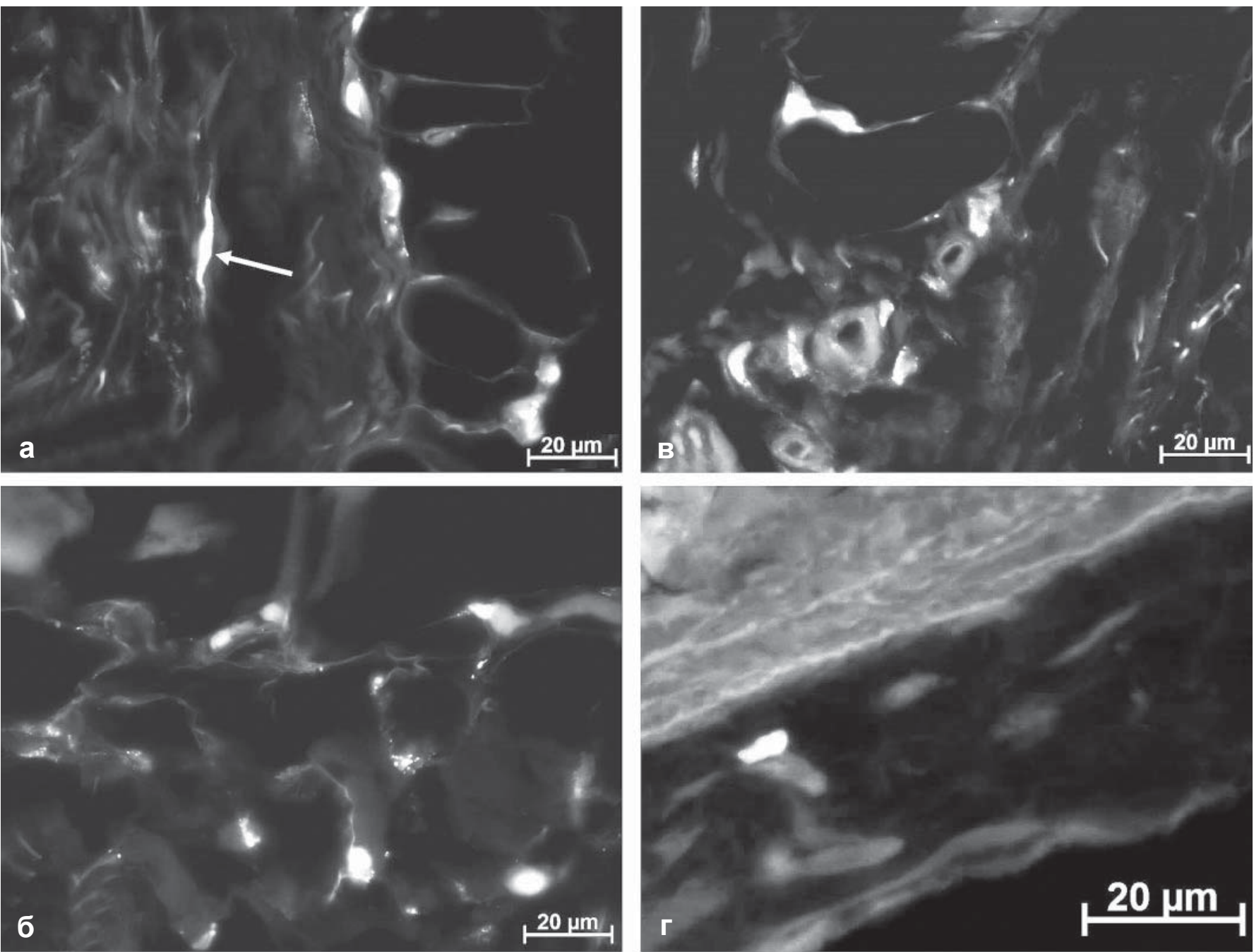

Puc. 1 .

Muкрофото.

Склерозированная клетчатка вокруг ииплантированного ПЛ с адсорбированными АМмСККПу крыс после операции, результат компьютерного совмешения изображений, полученных с применением фильтров Аlеха 488 и родаминового: a - через 1 нед (стрелкой указан участок цитоплазмы, который интенсивно и равномерно светится при использовании родаминового фбльтра); б - через 2 нед (ярко фбуоресиирующие многочисленные овальные включения различных размеров в цитоплазме); в - через 3 нед (овальные включения различных размеров светятся менее интенсивно, чем через 2 нед); 2 - через 4 нед (единичный, интенсивно светящийся объект расположен рядом с капсулой вокруг ПЛ).

меров за счет единичных мелких включений в цитоплазме, значительно чаще расположенных рядом с сосудами. Интенсивность флуоресценции была намного меньше по сравнению с таковой через 2 нед после операции (рис. 1, в).

В конце эксперимента очень редко, только при тщательном поиске, можно было найти объекты, ярко светящиеся в условиях применения родаминового фильтра (рис. 1, 2).

По данным световой просвечивающей микроскопии через 1 нед после операции ПЛ без адсорбированных АММСККП был окружен тонким слоем соединительной ткани, фактически похожей на склерозированные участки подкожно-жировой клетчатки. В цитограмме клеточных элементов образующейся капсулы преобладали фибробласты, лимфоциты и макрофаги. Обращали на себя внимание очень крупные макрофаги, расположенные небольшими группами (рuс. 2, $a$, б).
Вокруг ПЛ с адсорбированными АМмСККП отмечали визуально несколько меньший объем соединительной ткани, образующейся в подкожно-жировой клетчатке для отграничения инородного тела, и большее содержание мелких тонкостенных кровеносных сосудов, похожих на грануляции, в этой соединительной ткани (рис. 2, в, г).

Спустя 2 нед выраженность склероза в подкожно-жировой клетчатке, непосредственно примыкающей к ПЛ, увеличилась, там появилась типичная плотная волокнистая соединительная ткань. Однако даже в эти сроки полноценная капсула вокруг ПЛ отсутствовала. Склеротически измененные ткани непосредственно присоединялись к инородному телу, и при препаровальных процедурах и изготовлении гистологических срезов ПЛ фактически отрывался от окружающих тканей. В такой склерозированной клетчатке и капсулоподобных разрастаниях соединительной ткани было очень много мелких сосудов, по- 


\section{Kиініна хірургія Kifnichna khirurhita}

хожих на грануляции, и макрофагов. Однако слившихся многоядерных форм макрофагов еще не обнаруживали. Результаты имплантации чистого ПЛ и ПЛ с адсорбиро- ванными АММСККП визуально не отмечались (рис. 2, д, e).

К 3-й неделе вокруг имплантированного ПЛ как без, так и с адсорбированными АММСККП отмечено форми-
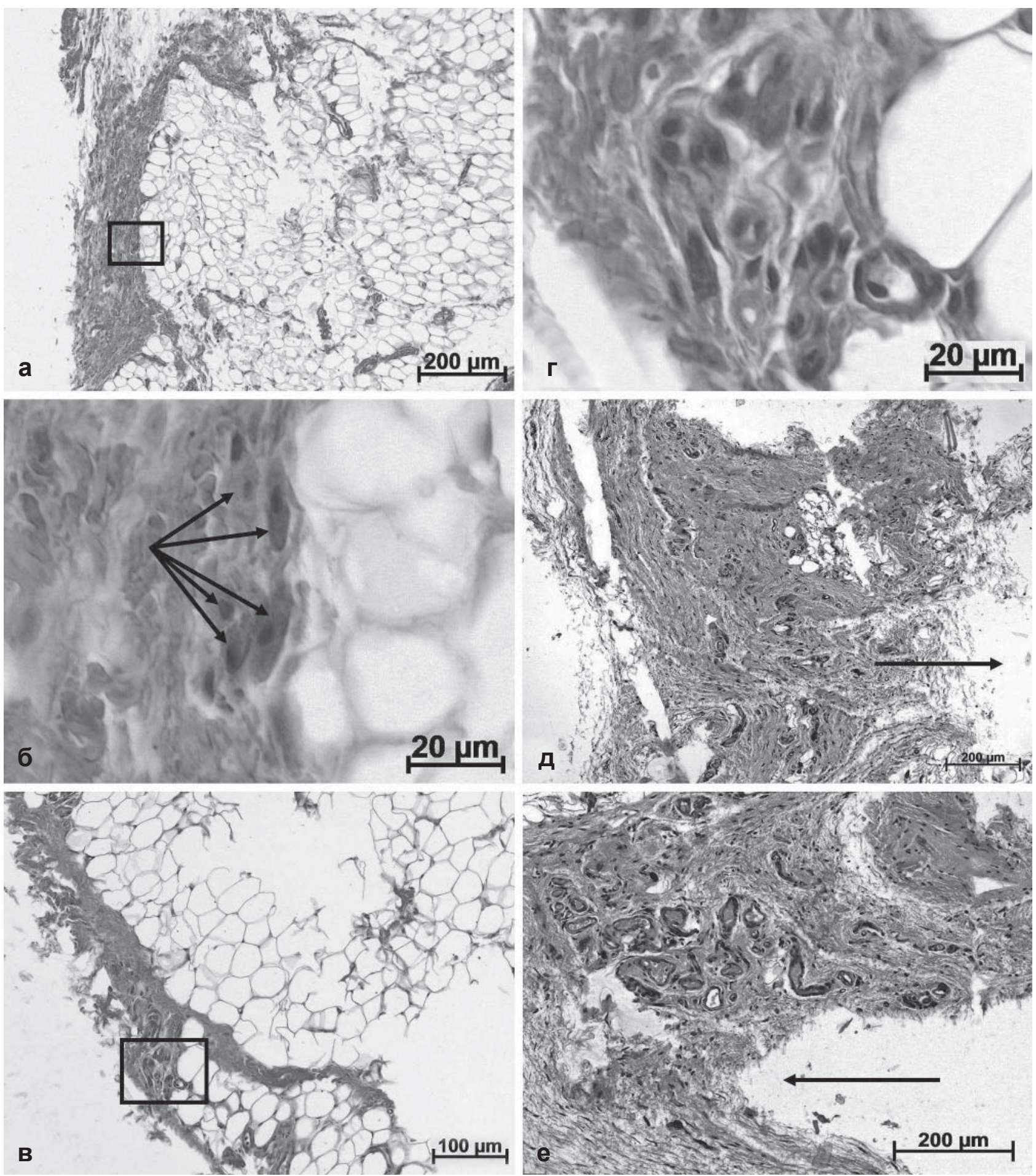

Puc. 2.

микробото

Особенности склероза подкожно-жировой клетчатки крыс в ранние сроки после илплантащии Пл,

окраска гематоксилином и эозином: а - через 1 нед ПЛ, имплантированный без АММСККП, окружен только уплотненной склерозированной клетчаткой; б - хаотично расположенные волокна и группы крупных макрофагов (указаны стрелками);

в - после внедрения ПЛ с адсорбированными АММСККП уровень склеротической трансбормачии подкожно-жировой клетчатки меньше; г - на участках склероза больие мелких тонкостенных сосудов; д - через 2 нед капсуль вокруг Пл без АММСККП нет (место ПЛ указано стрелкой); е - структур капсулы вокруг ПЛ с адсорбированными АММСККП нет (место Пл указано стрелкой). 


\begin{tabular}{|c|c|c|c|c|c|}
\hline Таблица 1. & \multicolumn{5}{|c|}{$\begin{array}{l}\text { Структурная организация рыхлой волокнистой соединительной ткани вокруг ПЛ, } \\
\text { имплантированного без АММСКП (S } \pm \text { б) }\end{array}$} \\
\hline \multirow{2}{*}{\multicolumn{2}{|c|}{ Параметры }} & \multicolumn{4}{|c|}{ Срок после имплантации, нед } \\
\hline & & 1 & 2 & 3 & 4 \\
\hline \multicolumn{2}{|c|}{ Ширина ткани, мкм } & $254 \pm 55,5^{4}$ & $381 \pm 40,4^{3,4}$ & $195 \pm 39,4^{2}$ & $123 \pm 26,1^{1,2}$ \\
\hline \multicolumn{2}{|c|}{ Кровеносные капилляры, $A_{A}$} & $3,93 \pm 0,884^{2}$ & $8,13 \pm 1,13^{1,4}$ & $5,73 \pm 1,44$ & $4,13 \pm 0,64^{2}$ \\
\hline \multicolumn{2}{|c|}{ Лимфатические капилляры, $\mathrm{A}_{\mathrm{A}}$} & $3,6 \pm 1,12^{3,4}$ & $6,53 \pm 1,41$ & $9,4 \pm 1,55^{1}$ & $9,47 \pm 2,7^{1}$ \\
\hline \multicolumn{2}{|c|}{ Численная плотность всех клеток, $\mathrm{N}_{\mathrm{A}}$} & $373 \pm 88,4^{2}$ & $953 \pm 203^{1,3,4}$ & $507 \pm 88,4^{2}$ & $490 \pm 89^{2}$ \\
\hline \multirow{2}{*}{ Лимфоциты } & $\%$ & $61,2 \pm 4,2^{2}$ & $38,3 \pm 4,96^{1,3}$ & $53 \pm 3,09^{2}$ & $51,3 \pm 9,26$ \\
\hline & $\mathrm{N}_{\mathrm{A}}$ & $227 \pm 50,2$ & $365 \pm 89,5$ & $267 \pm 40,3$ & $254 \pm 72,2$ \\
\hline \multirow{2}{*}{ Нейтрофилы } & $\%$ & $19,9 \pm 2,39^{2,3,4}$ & $28,1 \pm 3,07^{1,3,4}$ & $8,07 \pm 1,03^{1,2}$ & $6,87 \pm 1,41^{1,2}$ \\
\hline & $\mathrm{N}_{\mathrm{A}}$ & $75 \pm 23,2^{2}$ & $269 \pm 67,3^{1,3,4}$ & $40,5 \pm 6,49^{2}$ & $33,6 \pm 8,53^{2}$ \\
\hline \multirow{2}{*}{ Эритроциты } & $\%$ & $4,6 \pm 0,986^{2,4}$ & $7,93 \pm 0,79^{1,3,4}$ & $2,8 \pm 0,775^{2}$ & $1,93 \pm 0,799^{1,2}$ \\
\hline & $\mathrm{N}_{\mathrm{A}}$ & $17,3 \pm 6,37^{2}$ & $75,5 \pm 17,2^{1,3,4}$ & $14,3 \pm 5,01^{2}$ & $9,23 \pm 3,62^{2}$ \\
\hline \multirow{2}{*}{ Макрофаги } & $\%$ & $6,07 \pm 1,33^{2,3,4}$ & $12,7 \pm 1,62^{1,3,4}$ & $24,7 \pm 2,99^{1,2}$ & $26,9 \pm 3,23^{1,2}$ \\
\hline & $\mathrm{N}_{\mathrm{A}}$ & $22,9 \pm 8,21^{2,3,4}$ & $121 \pm 29,2^{1}$ & $127 \pm 34^{1}$ & $131 \pm 26,5^{1}$ \\
\hline Примечание. & \multicolumn{5}{|c|}{$\begin{array}{l}\mathrm{A}_{\mathrm{A}} \text { - относительная площадь структур на срезе }(\%) ; \mathrm{N}_{\mathrm{A}} \text { - численная плотность клеток на } 10^{5} \text { мкм² площади } \\
\text { среза; }{ }^{1} \text { - величина достоверно отличается от соответствующей величины через } 1 \text { нед после имплантации, } \\
{ }^{2} \text { - через }{ }^{2} \text { нед после имплантации, }{ }^{3}-\text { через } 3 \text { нед после имплантации, }{ }^{4}-\text { через } 4 \text { нед после имплантации } \\
(\mathrm{p} \leq 0,05) \text {. То же в табл. } 2 \text {. }\end{array}$} \\
\hline
\end{tabular}

рование типичной капсулы из плотной волокнистой соединительной ткани. При этом степень склеротической трансформации окружающей подкожно-жировой клетчатки значительно снизилась, также резко уменьшились васкуляризация и выраженность лейкоцитарной инфильтрации. В жировой ткани с незначительным склерозом было расположено инкапсулированное инородное тело. Толщина капсулы обычно не превышала 0,2 мм. Рядом с ПЛ в толще капсулы и сразу за ее пределами были расположены гигантские клетки инородных тел, формирующие гранулемы от небольших до очень обширных, диаметром более 100 мкм. Внутри капсулы по краю полимера были расположены тканевые структуры с очень значительным числом макрофагов, большинство из которых были похожи на гигантские клетки инородных тел (рuс. 3, a, б).

К 4-й неделе ПЛ, независимо от применения клеточных технологий в процессе имплантации, по-прежнему окружен капсулой из плотной волокнистой соединительной ткани, далее расположены структуры склерозированной подкожно-жировой клетчатки. Внутренний слой капсулы, непосредственно прилегающий к инородному телу, часто плотно с ним срастался, и полимер можно было удалить только с трудом, о чем свидетельствовали разрывы тканей, видные на микроскопическом уровне. Также часто внутренний слой капсулы представлял собой ряд гигантских клеток инородных тел, иногда создавалось впечатление, что один гигантский многоядерный макрофаг окутывал весь большой внедренный фрагмент ПЛ. Попрежнему в толще капсулы и рядом с ней были расположены разные по размерам гранулемы инородного тела, в которых иногда был виден инородный материал, окруженный гигантскими клетками инородных тел (рuс. 3, в, 2).

Исследованные морфометрические показатели капсулы, обнаруженной вокруг ПЛ только на 3-й и 4-й неделях после имплантации, такие как объем, васкуляризация и цитограмма тканевых лейкоцитов, были относительно постоянными в течение указанного срока и не зависели от использования клеточных технологий.

Ширина слоя склерозированной подкожно-жировой клетчатки вокруг ПЛ, имплантированного без АММСККП, через 3 нед после операции была меньше на 95,4\%, чем на 2-й неделе. К 4-й неделе этот показатель стал ниже в 2,1 и 3,1 раза соответственно по сравнению с его величиной на 1-й и 2-й неделях (табл. 1).

Объемная плотность кровеносных капилляров в склерозированной клетчатке вокруг ПЛ спустя 2 нед после имплантации была больше в 2,1 раза и на 96,9\% соответственно по сравнению с этим показателем на 1-й и 4-й неделях.

Объемная плотность лимфатических капилляров через 3 и 4 нед увеличилась в 2,6 раза по сравнению с этим показателем на 1-й неделе.

Толщина слоя склерозированной подкожно-жировой клетчатки спустя 1 и 2 нед после имплантации ПЛ с АММСККП была меньше в 2 раза и на 50,6\% соответственно, а объемная плотность кровеносных капилляров была больше в 2,2 раза и на 73,4\% соответственно по сравнению с аналогичными показателями после имплантации без использования АММСККП (табл. 1, 2).

Численная плотность всех клеток в склерозированной подкожно-жировой клетчатке вокруг ПЛ, имплантированного без АММСККП, через 2 нед после операции была болыше соответственно в 2,6 раза, на 88 и 94,5\%, чем через 1, 3 и 4 нед.

Относительное количество лимфоцитов в склерозированной клетчатке вокруг ПЛ через 2 нед после имплантации было меньше соответственно на 59,8 и 38,4\%, чем через 1 и 3 нед.

Относительное количество нейтрофилов на срезе клетчатки вокруг ПЛ через 2 нед после операции увеличилось на 41,2\% по сравнению с состоянием на 1-й неделе. Таких лейкоцитов к 3-й неделе было меньше соответствен- 


\section{Kиінічна хірургін Klinichna khirurhifa}

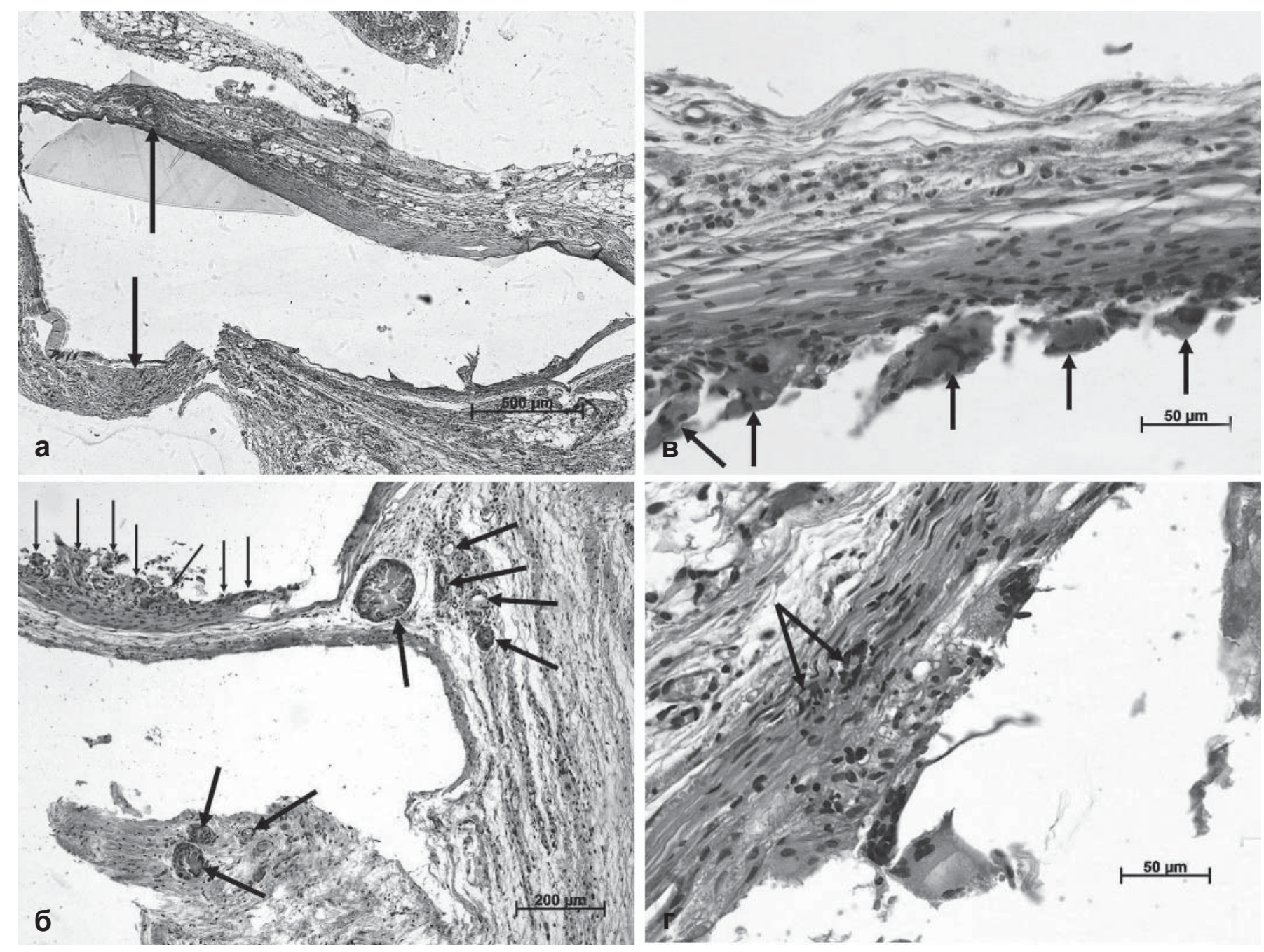

Puc.3.

Микрофото

Формирование капсулы вокруг инплантированного Пл в поздние сроки после операщии, окраска гематоксилином и эозином: а - через 3 нед ПЛ без АММСККП окружает тонкая капсула, рядом с ней в подкожно-жировой клетчатке расположены гранулемы, иногда оченъ обширные (указаны стрелками); б - вокруг ПЛ с адсорбированными АМмСККП сформирована тонкая капсула, внутри ее со стороны полимера расположено много макрофагов, в том числе гигантские клетки инородных тел

(указаны тонкими стрелками), в подкожно-жировой клетчатке содержатся многочисленные мелкие и очень крупные гранулемы, иногда с инородным материалом внутри (указаны толстыми стрелками); в - через 4 нед на внутренней поверхности капсулы вокруг ПЛ без АММСККП присутствуют многочисленные гигантские клетки инородных тел (указанъ стрелками); г - капсула вокруг ПЛ с адсорбированными АММСККП и окружающал клетчатка содержат мелкие гранулемы с инородным материалом (указаны стрелками), поверхность капсулы со стороны Пл практически является одной большой гигантской клеткой инородного тела.

но в 2,5 и 3,5 раза, чем на 1-й и 2-й неделях. Спустя 4 нед данный показатель уменьшился соответственно в 2,9 и 4,1 раза также по сравнению с 1-й и 2-й неделями. Абсолютное количество нейтрофильных лейкоцитов ко 2-й неделе после операции было выше соответственно в 3,6, 6,6 и 8 раз, чем на 1,3-й и 4-й неделях.

Относительное количество эритроцитов через 2 нед после операции было больше соответственно на 72,4\%, 2,8 и 4,1 раза, чем на 1, 3-й и 4-й неделях. К 4-й неделе этот показатель уменышился в 2,4 раза по сравнению с 1 -й неделей.

Численная плотность клеток красной крови в склерозированной подкожно-жировой клетчатке вокруг Пл, имплантированного без АММСККП, через 2 нед после операции была выше соответственно в 4,4, 5,3 и 8,2 раза, чем на 1, 3-й и 4-й неделях.
Относительное количество макрофагов на срезе клетчатки вокруг ПЛ через 2 нед после операции увеличилось в 2,1 раза по сравнению с состоянием на 1 -й неделе. Таких фагоцитов к 3-й неделе стало больше соответственно в 4,1 раза и на 94,5\%, чем на 1-й и 2-й неделях. Спустя 4 нед данный показатель возрос соответственно в 4,4 и 2,1 раза по сравнению с 1 -й и 2-й неделями.

Численная плотность макрофагов в склерозированных тканях рядом с ПЛ спустя 2, 3 и 4 нед после его имплантации без использования АММСККП увеличилась соответственно в 5,3, 5,5 и 5,7 раза относительно состояния на 1-й неделе.

Спустя 1 нед после имплантации ПЛ с АММСККП численная плотность всех клеток и лимфоцитов была соответственно меньше в 2 и 2,3 раза, а относительное количе- 


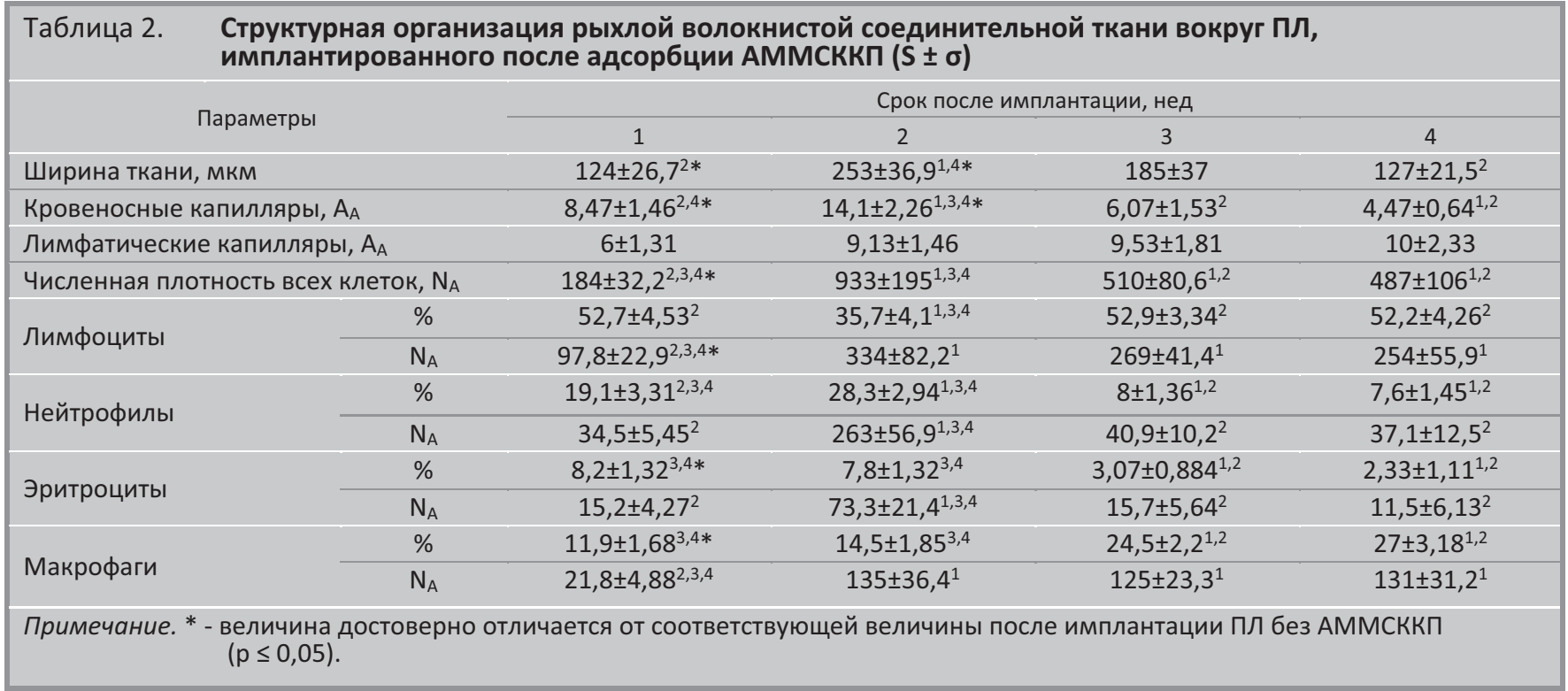

ство эритроцитов и макрофагов больше соответственно на 78,3 и 96\%, чем после имплантации Пл без АММСККП.

\section{Обсуждение}

Наиболее вероятно, что обнаруженными на 1-й неделе после имплантации с помощью люминесцентной микроскопии фибробластоподобными клеточными элементами с интенсивным равномерным свечением больших участков цитоплазмы при использовании родаминового фильтра являются АММСККП, введенные вместе с ПЛ, мембраны которых были окрашены Vybrant-CM-Dil. MCK не погибают сразу после имплантации в организм на поверхности ПЛ, а мигрируют, по крайней мере, частично в окружающие ткани.

На 2-й неделе, по крайней мере, большинство из светящихся в условиях применения родаминового фильтра клеточных элементов, скорее всего, являются макрофагами, фагоцитировавшими сами АММСККП или их детрит. В таком случае ярко светящиеся разнокалиберные включения в этих фагоцитах являются лизосомами с поглощенным флуоресцентным материалом. Макрофаги, поглощая AMМСККП и их детрит с окрашенными Vybrant-CM-Dil мембранами, накапливают окрашенные фрагменты и сам краситель в лизосомах. В результате содержимое лизосом и их мембраны также начинают интенсивно флуоресцировать под влиянием ультрафиолетового света, проходящего через родаминовый фильтр. При этом не исключено окрашивание Vybrant-CM-Dil не только лизосом, но и других мембранных структур фагоцитов. Следует учитывать, что макрофаги постепенно могут фагоцитировать, при условии успешной деградации, очень большой объем детрита, вследствие этого концентрация VybrantCM-Dil в фагоцитах может стать очень значительной и они приобретут способность к люминесценции намного большую, чем поглощенные окрашенные АММСККП или их детрит [9, 11].
Объем детрита АММСККП рядом с ПЛ постепенно уменьшается, и макрофаги содержат в своих лизосомах все меньше красителя. Вследствие этого к 3-й неделе уменьшаются как число флуоресцирующих лизосом, так и интенсивность их свечения. На снижении яркости свечения и количества флуоресцирующих клеток может сказаться и теоретически возможная миграция макрофагов с детритом АММСККП из капсулы вокруг ПЛ и окружающей ее подкожно-жировой клетчатки в другие органы и структуры, например, регионарные лимфатические узлы [8]. Постепенное удаление макрофагами адсорбированных на ПЛ и окрашенных Vybrant-CM-Dil АММСККП к 4-й неделе привело к практически полной элиминации этих клеточных элементов и их детрита из тканей в месте имплантации.

Подкожно-жировая клетчатка повреждается при формировании в ней канала для имплантации и в процессе самого внедрения инородного тела - ПЛ. При регенерации поврежденные участки замещаются соединительной тканью, что является естественным и благоприятным исходом репаративных процессов.

Полимер, даже созданный из биологически совместимых материалов, также постепенно инкапсулируется соединительной тканью, которая замещает кровь и фибрин, первоначально изолирующие инородное тело от организма. Со временем соединительная ткань на месте сформированного канала для внедрения Пл подвергается обратному развитию, а вокруг полимера - уплотняется и служит основой для формирования капсулы.

В связи с реакциями на повреждение в ткани в месте хирургического разреза, формирования канала и вокруг ПЛ мигрируют лейкоциты и развивается асептическая воспалительная реакция, которая со временем затихает, но полностью не прекращается, так как ее причиной уже являются не травмированные во время операции ткани, а присутствие в них инородного тела. Так как воспалитель- 
ный процесс асептический, среди тканевых лейкоцитов преобладают лимфоциты и макрофаги, а не нейтрофилы. Не исключено, что цитоплазма макрофагов, расположенных рядом друг с другом, со временем сольется и из групп этих фагоцитов образуются большие многоядерные объекты со слившейся цитоплазмой - гигантские клетки инородных тел.

На 2-й неделе продолжается изоляция инородного тела от организма соединительной тканью, которая со временем становится все толще и приобретает плотный волокнистый характер. Вокруг внедренного ПЛ нарастает асептическая воспалительная реакция, о чем свидетельствуют многочисленные грануляции, появляющиеся на месте поврежденных тканей и структур в процессе их замещения соединительной тканью, а также лейкоцитарная инфильтрация тканей рядом с имплантатом.

Пик численной плотности всех лейкоцитов на 2-й неделе совпадает с результатами, показывающими максимальную выраженность воспалительной реакции в ответ на внедрение ПЛ именно в этот срок. Происходит нарастание объема поврежденных при имплантации тканей, так как возможно дополнительное повреждение клетчатки кислыми мономерами молочной кислоты [15], образовавшимися вследствие деградации полимера. Поврежденные и нежизнеспособные ткани обладают антигенными свойствами и туда мигрируют лейкоциты.

По-видимому, усиление васкуляризации и высокое содержание эритроцитов в тканях рядом с полимером на 2-й неделе после операции также отражает нарастание интенсивности воспаления и максимальную выраженность склероза. Воспалительный процесс всегда сопровождается микроциркуляторными нарушениями, можно наблюдать явления тромбоза, эмболизации кровеносных капилляров, что предохраняет организм от гематогенной диссеминации антигенов и инфекции, сепсиса. Стаз крови и повреждение эндотелия кровеносных сосудов приводит к диапедезу форменных элементов крови и даже к геморрагиям. Все это является одной из причин увеличения численности эритроцитов в тканях.

Поврежденные структуры подкожно-жировой клетчатки подвергаются склерозу, а одним из этапов удаления некротизированных тканей и образования на их месте рубца является развитие грануляций, характеризующихся высоким содержанием мелких тонкостенных кровеносных сосудов. Тонкая оболочка сосудов грануляционной ткани легко повреждается, и это также может служить одной из причин появления и увеличения содержания свободных эритроцитов в подкожно-жировой клетчатке вокруг имплантированного ПЛ.

Вследствие воспаления и активных процессов развития кровеносных сосудов усиливается и лимфатическая васкуляризация. Однако лимфатические сосуды растут гораздо медленнее кровеносных. Не исключено, что такое нарастание лимфатической васкуляризации обусловлено восстановлением нормальной структуры подкожножировой клетчатки после инкапсуляции ПЛ, уменьше- нием склеротической трансформации жировой ткани.

Фибробласты вместе с лейкоцитами фагоцитируют продукты деградации ПЛ и начинают синтез компонентов соединительной ткани. В результате ее структуры плотно прирастают к деградирующему краю ПЛ. По-видимому, вследствие этого сразу не происходит формирования полноценной капсулы для отграничения инородного тела, при попытке отделить его от окружающих тканей последние разрываются, часть их остается на поверхности удаленного ПЛ.

На основании полученных результатов и сопоставления их с литературными данными можно заключить, что ПЛ, несмотря на свою биосовместимость, все-таки вызывает миграцию лейкоцитов и изолируется соединительной тканью. Вместе с этим даже через 2 нед после имплантации вокруг полимера отсутствуют типичная капсула и гигантские клетки инородных тел.

Спустя 3 нед прогрессирующее развитие плотной волокнистой соединительной ткани по краю ПЛ привело к формированию типичной капсулы, как это происходит и вокруг других инородных тел. Капсула изолирует ПЛ от окружающих тканей, при его деградации в ткани поступает меньше кислых продуктов, повреждающих подкожно-жировую клетчатку.

Отсутствие различий в структурной организации капсулы вокруг ПЛ как в зависимости от срока исследования, так и в зависимости от использования клеточных технологий, во-первых, свидетельствует о хорошо сформированной плотной волокнистой соединительной ткани, окружающей имплантированный ПЛ, во-вторых, длительное время, прошедшее с момента попадания АММСККП, адсорбированных на ПЛ, в организм, по-видимому, нивелировало возможное влияние клеточных технологий на инкапсуляцию ПЛ и структуру сформированной капсулы. Учитывая отсутствие влияния АММСККП, адсорбированных на ПЛ, на толщину, структуру и сроки формирования вокруг него капсулы, можно сделать заключение о том, что уменьшение степени склеротической трансформации подкожно-жировой клетчатки является благоприятным эффектом клеточной терапии. Применение МСК не влияет на степень фиксации полимера капсулой, наоборот, снижение активности воспаления вокруг нее должно улучшить функционирование капсулярных тканей.

Изменения объема склерозированных тканей и интенсивности воспаления полностью отражают особенности реакций организма на ПЛ. В первые 2 нед после имплантации вследствие присутствия инородного тела склероз и лейкоцитарная инфильтрация подкожно-жировой клетчатки нарастают. Затем, по мере формирования капсулы вокруг ПЛ, предохраняющей окружающие ткани от повреждения как самим инородным телом, так и кислыми продуктами его деградации [15], степень склеротической трансформации клетчатки вокруг капсулы и активность воспалительного процесса резко и быстро снижаются. Это проявляется в снижении выраженности васкуляризации и лейкоцитарной инфильтрации: уменьшается со- 
держание нейтрофилов при одновременном увеличении численности лимфоцитов.

Содержание макрофагов медленно возрастало все время наблюдения, что, по-видимому, обусловлено, как процессами макрофагальной деградации имплантированного ПЛ, в том числе и с формированием гигантских клеток инородных тел и развитием гранулем, так и процессами инкапсуляции плотной волокнистой соединительной тканью внедренного инородного материала - макрофаги принимают активное участие в образовании и функционировании самой соединительной ткани, обмене ее межклеточного матрикса.

Возможно, что вследствие именно этого в капсуле по краю полимера было найдено множество макрофагов, в том числе и их слившиеся многоядерные формы. Макрофаги мигрируют в просвет капсулы к краю Пл, разжижают за счет экзоцитоза лизосомальных ферментов [16] и фагоцитируют периферию инородного тела, при этом для поглощения больших фрагментов ПЛ из макрофагов формируются гигантские клетки инородных тел.

На 4-й неделе продолжается разрушение имплантированного ПЛ макрофагами, которые выстраиваются вдоль края ПЛ по внутренней стороне капсулы, образуя гигантские многоядерные формы. Фагоциты плотно консолидируются с инородным телом, проникая в его микропоры и окружая выступы, происходит плотное сращение ПЛ с капсулой и окружающими тканями.

Не исключено, что в силу определенной разнородности ПЛ отдельные его фрагменты «отрезаются» фагоцитами и инкапсулируются вместе с макрофагами своей собственной соединительнотканной капсулой, которая потом сливается с капсулой вокруг всего инородного тела, и мелкий его фрагмент оказывается в толще основной капсулы, постепенно перемещаясь за счет действия миофибробластов наружу. Постепенно такой инкапсулированный вместе с фагоцитами фрагмент ПЛ оказывается в подкожно-жировой клетчатке за пределами «большой» капсулы, и таким образом формируются мелкие и крупные гранулемы рядом с имплантированным Пл.

Степень склеротической трансформации подкожножировой клетчатки после имплантации Пл с адсорбированными АММСККП меньше, чем после внедрения полимера без применения АММСККП, даже при одном и том же уровне повреждения. Основной причиной таких различий, скорее всего, служит антифибротическое действие клеточных технологий [17]. Также на снижении объема образующейся соединительной ткани может сказаться иммуномодуляторное действие адсорбированных на ПЛ АММСККП [3 - 6]. За счет подавления активности воспалительного процесса уменьшается степень повреждения тканей вокруг полимера лизосомальными ферментами лейкоцитов [16], и соответственно толщина соединительнотканных структур, изолирующих инородное тело, становится меныше.

На 1-й неделе после имплантации Пл с АММСККП была меньше численная плотность всех лейкоцитов и лимфоцитов при одновременном увеличении содержания относительного числа эритроцитов и макрофагов, чем после имплантации ПЛ без АММСККП.

Такие отличия и именно через 1 нед после внедрения ПЛ с адсорбированными АММСККП, наиболее вероятно, обусловлены также иммуномодуляторным действием клеточных технологий [3 - 6]. Прикрепленные к поверхности полимера МСК при попадании в ткани или сами по себе оказывают противовоспалительный эффект [4, 6], или такое влияние стало результатом действия экзосом, экстрацеллюлярных везикул и детрита, оказавшихся в тканях вокруг места имплантации при деструкции этих клеточных элементов [3, 5].

Так как АММСККП подавляют активность воспалительного процесса [3 - 6], в тканях рядом с инородным телом уменьшается численная плотность всех лейкоцитов и особенно лимфоцитов. Следует отметить, что сами по себе МСК и их экзосомы подавляют пролиферацию лимфоцитов [18] и регулируют функциональную активность клеток миелоидного происхождения [5], что приводит к уменьшению численности лимфоцитов, а их место занимают макрофаги. Следует учитывать, что в результате применения АММСККП увеличилось относительное количество именно макрофагов, абсолютное количество фагоцитов на единицу площади среза ткани статистически достоверно не менялось.

За счет появления в тканях болышого количества МСК возможно ускоренное развитие сосудов грануляций в месте повреждения [7]. Скорее всего, в данном случае АММСККП или какая-то их часть участвует в формировании грануляций, встраиваясь в стенки растущих сосудов или целиком составляя их оболочки [7]. За счет этого грануляции образуются раныше и в большем количестве, что нашло отражение в усилении васкуляризации подкожно-жировой клетчатки. Такое действие АММСККП, адсорбированных на Пл, также является положительным, так как более быстрое и выраженное образование грануляций сразу после имплантации полимера должно способствовать более быстрому и раннему очищению раны и тканей вокруг инородного тела от детрита и более быстрому образованию рубца в области хирургического разреза. Все это вместе с иммуномодуляторным действием МСК [3 - 6] может способствовать снижению активности воспалительного процесса вокруг имплантата, а значит, и более успешным результатам всей процедуры по внедрению полимера молочной кислоты в ткани живого организма.

По-видимому, вследствие определенного несовершенства тонких оболочек молодых сосудов грануляционной ткани в подкожно-жировой клетчатке рядом с ПЛ с АММСККП после его внедрения было обнаружено большое число эритроцитов. Эти клеточные элементы также могут оказаться в тканях и в результате инволюции грануляций при замещении участков деструкции нормальными структурами или соединительной тканью, рубцом.

Все различия, связанные с адсорбцией АММСККП на Пл, были найдены только на первых неделях после имплантации. Это, скорее всего, объясняется элиминацией 
введенных АММСККП из места применения в неизмененном виде посредством сосудистого русла [10] или макрофагами в качестве детрита, находящегося в лизосомах [8, 9]. Литературные данные также подтверждают максимальную элиминацию введенных МСК, даже аутологичных, на 2 - 3-й неделе после применения [11].

\section{Выводы}

1. На основании изложенного можно заключить, что при имплантации ПЛ с адсорбированными АММСККП эти клеточные элементы оказываются в рядом расположенных тканях. Но уже к 2-й неделе все АММСККП из тканей фагоцитируются макрофагами, и в их лизосомах детрит АММСККП элиминируется из места введения практически полностью к 4-й неделе.

2. После имплантации ПЛ с адсорбированными АММСККП статистически достоверно уменьшается выраженность склероза подкожно-жировой клетчатки при увеличении ее васкуляризации на 1 - 2-й неделях после операции. В этой клетчатке в течение 1 -й недели активность воспалительной реакции ниже, о чем свидетельствует уменьшение численной плотности всех лейкоцитов и лимфоцитов при одновременном возрастании относительного количества макрофагов и эритроцитов, чем после имплантации ПЛ без АММСККП.

3. Типичная полноценная капсула из плотной волокнистой соединительной ткани вокруг имплантированного ПЛ у крыс формировалась только к 3-й неделе после операции, при этом внутренний слой капсулы часто представлял собой почти сплошной ряд гигантских клеток инородных тел. Сроки образования и исследованные морфометрические показатели этой капсулы, такие как объем, васкуляризация и цитограмма тканевых лейкоцитов, не зависели от использования клеточных технологий.

\section{Подтверждение}

Финансирование. Работа выполнена при финансовой поддержке ПФНИ ГАН на 2017-2020 гг. (VI.62.2.1, 0309-2016-0006) "Разработка технологий получения материалов для регенеративной медицины и развитие методов восстановления репродуктивного здоровья". Финансовой поддержки со стороны компаний-производителей оборудования, реактивов и лекарственных препаратов авторы не получали.

Участие авторов. И.В. Майбородин - концепция и дизайн исследования, анализ полученных данных, статистическая обработка, написание текста, редактирование; Т.В. Михеева - сбор и обработка материала, анализ полученных данных; В.И. Майбородина - сбор и обработка материала, анализ полученных данных, статистическая обработка; А.И. Шевела -концепция и дизайн исследования, редактирование.

Все авторы прочитали и одобрили окончательный вариант рукописи.

Конфликт интересов. Авторы заявляют об отсутствии конфликта интересов.
Одобрение комитета по этике. Исследование одобрено локальным этическим комитетом Центра новых медицинских технологий Института химической биологии и фундаментальной медицины СО РАН.

Согласие на публикацию. Все авторы дали согласие на публикацию этой рукописи.

\section{References}

1. Nofar M, Sacligil D, Carreau PJ, Kamal MR, Heuzey MC. Poly (lactic acid) blends: Processing, properties and applications. Int J Biol Macromol. 2019;125:307-60. doi: 10.1016/j.ijbiomac.2018.12.002.

2. Maiborodin IV, Kuznetsova IV, Beregovoy EA, Shevela AI, Maiborodina VI, Manaev AA, et al. Absence of complete resorption of polylactide material in the organism. Novosti Khirurgii. 2014;22(1): 26-32. doi: 10.18484/2305-0047.2014.1.26. [In Russian].

3. Shree N, Venkategowda S, Venkatranganna MV, Bhonde RR. Treatment with adipose derived mesenchymal stem cells and their conditioned media reverse carrageenan induced paw oedema in $\mathrm{db} / \mathrm{db}$ mice. Biomed Pharmacother. 2017;90:350-3. doi: 10.1016/j.biopha.2017.03.090.

4. Qiu G, Zheng G, Ge M, Huang L, Tong H, Chen P, et al. Adipose-derived mesenchymal stem cells modulate CD14(++)CD16(+) expression on monocytes from sepsis patients in vitro via prostaglandin E2. Stem Cell Res Ther. 2017;8(1):97. doi: 10.1186/s13287-017-0546-x.

5. Tang XD, Shi L, Monsel A, Li XY, Zhu HL, Zhu YG, et al. Mesenchymal stem cell microvesicles attenuate acute lung injury in mice partly mediated by Ang-1 mRNA. Stem Cells. 2017;35(7):1849-59. doi: 10.1002/stem.2619.

6. Takeyama H, Mizushima T, Uemura M, Haraguchi N, Nishimura J, Hata $\mathrm{T}$, et al. Adipose-derived stem cells ameliorate experimental murine colitis via tsp-1-dependent activation of latent TGF $-\beta$. Dig Dis Sci. 2017;62(8):1963-74 doi: 10.1007/s10620-017-4578-y.

7. Maiborodin IV, Morozov VV, Novikova JaV, Matveeva VA, Artemyeva LV, Matveev AL, et al. Acceleration of development of postoperative granulations after administration of mesenchymal stem cells near the thrombosed vein in experiment. Novosti Khirurgii. 2012;20(6):129. [In Russian].

8. Maiborodin IV, Matveeva VA, Maslov RV, Onoprienko NV, Kuznetsova IV, Chastikin GA. Fluorescent macrophages in the lymph nodes after application of multipotent mesenchymal stromal cells with transfected GFP gene. Novosti Khirurgii. 2014;22(5):526-32. doi: 10.18484/23050047.2014.5.526. [In Russian].

9. Maiborodin IV, Morozov VV, Anikeev AA, Figurenko NF, Maslov RV, Chastikin GA, et al. Macrophage reaction to multipotent mesenchymal stromal cells introduction into surgical trauma site in rats. Novosti Khirurgii. 2017;25(3):233-41. doi: 10.18484/2305-0047.2017.3.233. [In Russian].

10. Maiborodin IV, Maslov RV, Mikheeva TV, Elovskiy AA, Figurenko NF, Maiborodina VI, et al. The possibility of the angiogenesis in tissues remote from the place of the multipotent mesenchymal stromal cell injection. Molekulyarnaya meditsina. 2018;16(3):22-6. doi: 10.29296/24999490-2018-03-04. [In Russian].

11. Maiborodin IV, Maslov RV, Mikheeva TV, Elovskiy AA, Figurenko NF, Maiborodina VI, et al. Macrophagal adsorption of multipotent mesenchymal stromal cells and their debris from vascular bed proves the migration of these cellular elements through the vessels after tissue injection. Molekulyarnaya meditsina. 2018;16(3):56-61 doi: 10.29296/249994902018-04-10. [In Russian].

12. Krymskij LD, Nestajko GV, Rybalov AV. Rastrovaja jelektronnaja mikroskopija sosudov i krovi. Moskva: Medicina; 1976. 168 p. [In Russian].

13. Maiborodin IV, Elovskiy AA, Mikheeva TV, Figurenko NF, Maslov RV, Maiborodina VI, et al. The specific features of the inflammatory process accompanying ligation of the femoral vein in experiment under the 
conditions of stem cell therapy. Flebologiya. 2018;12(4):270-79. doi: 10.17116/flebo201812041270. [In Russian].

14. Head JR, Seeling LLJr. Lymphatic vessels in the uterine endometrium of virgin rats. J Reprod Immunol. 1984;6(3):157-66. PMID: 6737369.

15. Lee SK, Han CM, Park W, Kim IH, Joung YK, Han DK. Synergistically enhanced osteoconductivity and anti-inflammation of PLGA/ $\beta$ $\mathrm{TCP} / \mathrm{Mg}(\mathrm{OH})(2)$ composite for orthopedic applications. Mater Sci Eng C Mater Biol Appl. 2019;94:65-75. doi: 10.1016/j.msec.2018.09.011.

16. Fredriksson MI, Gustafsson AK, Bergström KG, Asman BE. Constitutionally hyperreactive neutrophils in periodontitis. J Periodontol. 2003;74(2):219-24. doi: 10.1902/jop.2003.74.2.219.

17. Li Y, Zhang W, Gao J, Liu J, Wang H, Li J, et al. Adipose tissue-derived stem cells suppress hypertrophic scar fibrosis via the p38/MAPK signaling pathway. Stem Cell Res Ther. 2016;7(1):102. doi: 10.1186/ s13287-016-0356-6.

18. Stenger EO, Chinnadurai R, Yuan S, Garcia M, Arafat D, Gibson G, et al. Bone marrow-derived mesenchymal stromal cells from patients with sickle cell disease display intact functionality. Biol Blood Marrow Transplant. 2017;23(5):736-45. doi: 10.1016/j.bbmt.2017.01.081.

Поступила 23.03.19 